\title{
1. Títol: Les forces i els estiraments
}

\section{Continguts teòrics}

La magnitud força es caracteritza com un vector amb un punt d'aplicació, una direcció d'actuació i sentit, i un valor (mòdul).

La unitat per mesurar forces és el Newton (N)

Els estiraments son tècniques per incrementar la mobilitat, utilitzant l'allargament de la musculatura i donar elasticitat.

Es fa aplicant una força suau i constant que repercutirà en l'allargament del teixit connectiu.

\section{Objectiu de la pràctica}

Identificar la força que actua en cada estirament, i caracteritzar-la (punt d'aplicació, direcció, sentit i valor en Newton). Identificar l'efecte en la musculatura.

\section{Material. Esquema}

Utilitza com unitat de 1Newton $(1 \mathrm{~N})$ un $\mathrm{cm}$ de longitud (pots fer servir un regle)

Una màrfega individual

A cada exercici marca:

- Punt d'aplicació: punt "P"

- Direcció d'aplicació: una recta discontinua en llapis

- Sentit d'aplicació: la punta d'una fletxa

- Mòdul: el valor en Newtons que està indicat a cada exercici (recorda que $1 \mathrm{~N}=1 \mathrm{~cm}$ )

- La zona on actua l'estirament amb un cercle groc
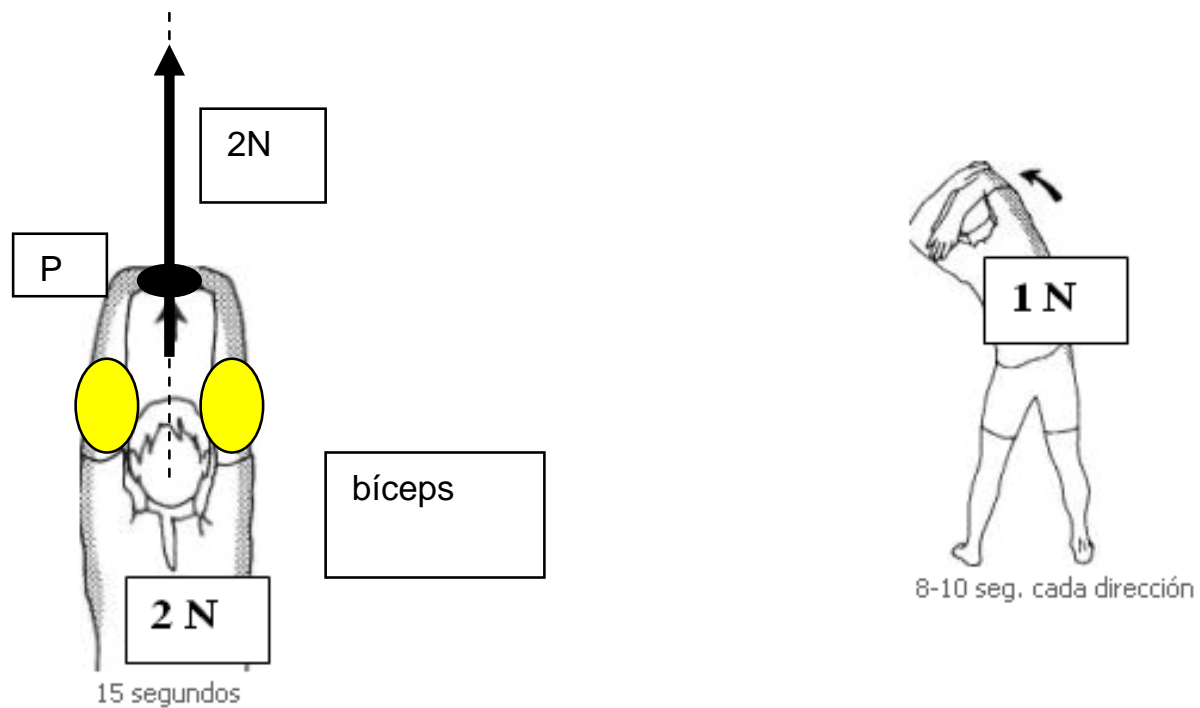

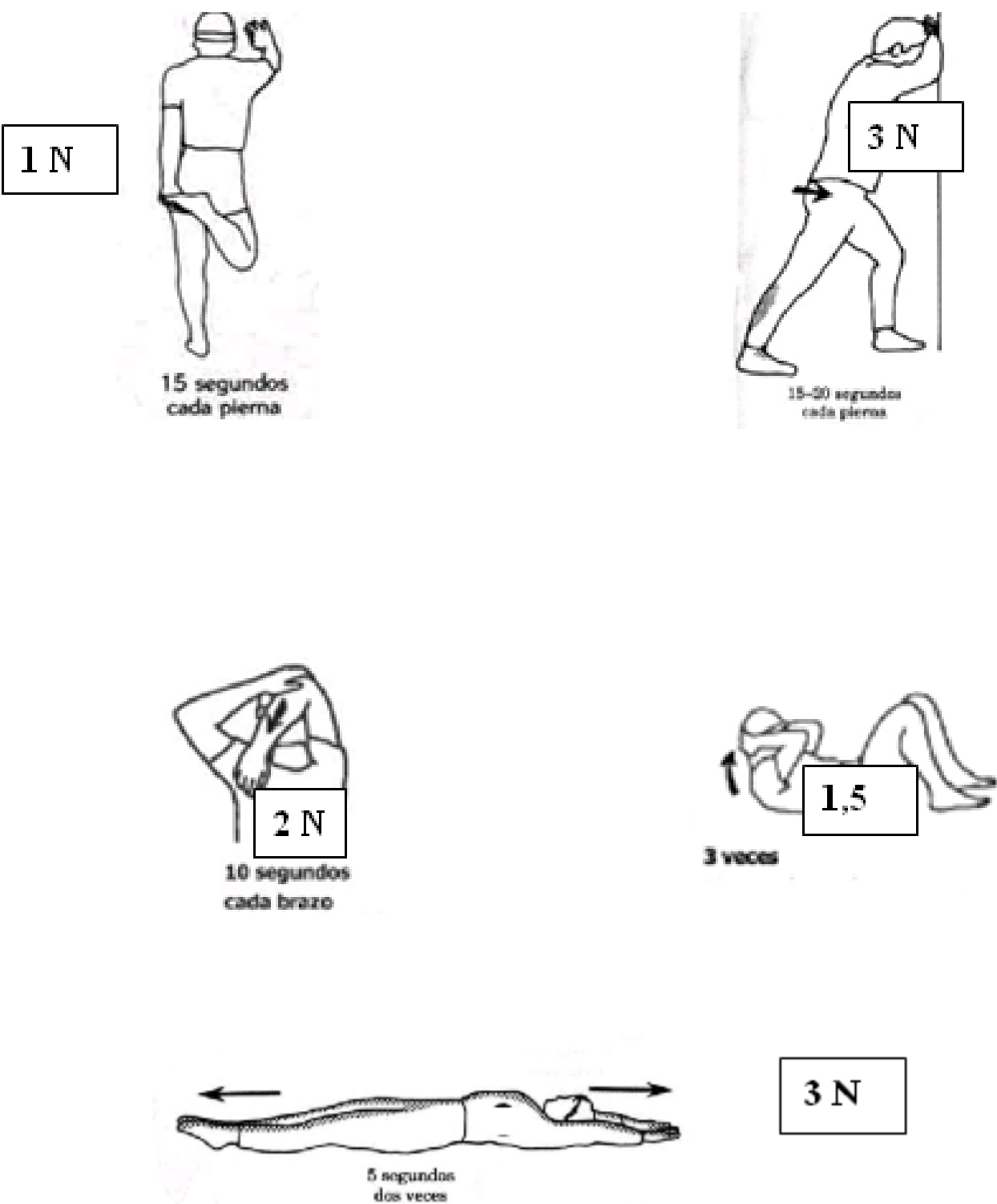

$3 \mathbf{N}$

\section{Conclusions}

- Quina es una lesió muscular que he patit en alguna situació ( jo o un amic/ga meu/va)

- Quina força puc aplicar i quin efecte tindrà per fer la prevenció d'aquesta lesió 